\title{
Caprilesia almirantiana gen. nov. and sp. nov. of Saicinae from Brazil (Hemiptera, Reduviidae)
}

\author{
Hélcio R. Gil-Santana ${ }^{\text {; }}$ Oton M. Marques $^{2} \&$ Luiz A. A. Costa ${ }^{3}$ \\ 1 Laboratório de Diptera, Departamento de Entomologia, Instituto Oswaldo Cruz. Avenida Brasil 4365, Manguinhos, \\ 21045-900 Rio de Janeiro, Rio de Janeiro,Brasil.E-mail: helciogil@uol.com.br \\ 2 Departamento de Fitotecnia, Centro de Ciências Agrárias e Ambientais, Universidade Federal da Bahia. 44380-000 Cruz \\ das Almas, Bahia, Brasil. E-mail: oton@ufba.br \\ ${ }^{3}$ Museu Nacional, Universidade Federal do Rio de Janeiro. 20940-040 Quinta da Boa Vista, Rio de Janeiro, Rio de Janeiro, Brasil.
}

\begin{abstract}
Caprilesia gen. nov. and C. almirantiana sp. nov. (type species) are described from Brazil, Bahia. Illustrations of the holotype and also a key for the American genera of Saicinae are presented.

KEY WORDS. Bahia; Heteroptera; Insecta; new taxa; taxonomy.
\end{abstract}

\begin{abstract}
RESUMO. Caprilesia almirantiana gen. nov. e sp. nov. de Saicinae do Brasil (Hemiptera, Reduviidae). Caprilesia gen. nov. e C. almirantiana sp. nov. (espécie-tipo) são descritos do Brasil, Bahia. Ilustrações do holótipo e uma chave para os gêneros Americanos de Saicinae são apresentados.

PALAVRAS-CHAVE. Bahia; Heteroptera; Insecta; novos taxa; taxonomia.
\end{abstract}

Saicinae is a tropicopolitan group that currently contains 23 genera, by far the largest of which are Polytoxus Spinola, 1840 from the Old World and Saica Amyot \& Serville, 1843 from the New World (Maldonado Capriles 1990, Blinn 1990, 1994, Schun \& Slater 1995, Melo \& Coscarón 2005).

The known genera in the New World are: Bagriella McAtee \& Malloch, 1923; Buninotus Maldonado Capriles, 1981; Oncerotrachelus Stål, 1868; Paratagalis Monte, 1943; Pseudosaica Blinn, 1990; Saica, Saicireta Melo \& Coscarón, 2005 and Tagalis Stål, 1860. In Brazil, species of the following ones were already referred: Oncerotrachelus, Paratagalis, Pseudosaica, Saica and Tagalis (Monte 1943, Wygodzinsky 1949, Putshkov \& PutshKov 1985, MaLdonado Capriles 1990, Blinn 1990, Gil-Santana \& Marques 2005, Melo \& Coscarón 2005).

A new genus and species of Saicinae from the State of Bahia, Brazil are herein described.

A key for the American Saicinae genera, based on Maldonado Capriles (1981), Blinn (1990) and Melo \& Coscarón (2005), including Caprilesia gen. nov. is presented.

\section{Key for the American Saicinae genera}

1. Forelegs without stout spines, at most with stiff erect setae ...2

1 '. Foretibiae with one and forefemora with two rows of stout spines (Figs 1-2) .....

2. Posterior pronotal lobe with upward projecting spines or tubercles; mesoscutum and scutellum with an upward projecting apical vertical spine or tubercle

2 '. Pronotum unarmed; apex of mesoscutum produced into a long horizontal tapering spine Oncerotrachelus

3. Opposed surfaces of beak and head with spine-like setae; forewing with 2-3 cells; metapleura without a tubercle near coxal cavity.

3.' Opposed surfaces of beak and head without spine-like setae or bristles; forewing with 4 cells; metapleura with a tubercle near coxal cavity Saicireta

4. Process on lower anterior angle of prothorax acute to subacute; antennal segment II subequal to $1 / 2$ the length of antennal segment I; process of male hypopygium bifurcate; posterior margin of abdominal segment sternum VII in females vertical to subvertical ......................... Saica

4 '. Process on lower anterior angle of prothorax subconical; antennal segment II subequal to $1 / 3$ the length of antennal segment I; process of male hypopygium a single, erect barbless spine; posterior margin of abdominal segment sternum VII in females sloping ventrocephalad.

Pseudosaica

5. Humeral angles of pronotum without processes, rounded Tagalis

$5^{\prime}$. Humeral angles of pronotum with spine like processes (Figs 1-2)

6 . Forecoxae and anterior lobe of pronotum unarmed; forewings with three closed cells ............................................ Bagriella

6 '. Forecoxae spined (Figs 2-3), anterior lobe of pronotum with four spines or rounded humps; forewings with two, three or four closed cells (Figs 1-3) ........................................... 7 


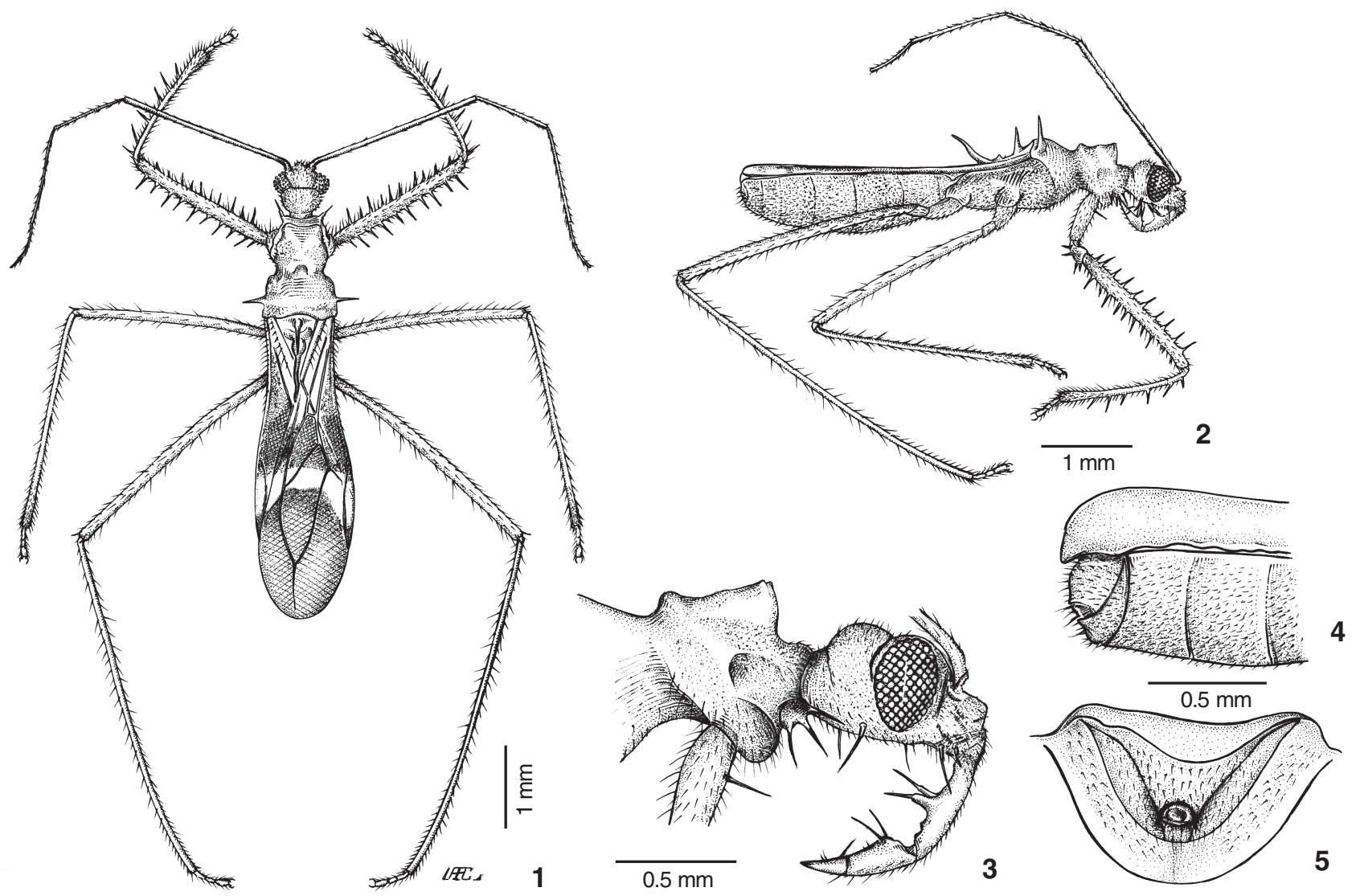

Figures 1-5. Caprilesia almirantiana sp. nov., holotype female: (1) dorsal view; (2) lateral view; (3) head and anterior portion of pronotum and anterior coxa, lateral view; (4) apex of abdomen, lateral view; (5) genital sclerites, caudal view.

7. Anterior lobe of pronotum with four long vertical spines, forewings with three closed cells; about $7 \mathrm{~mm}$ long.........

Paratagalis

7.' Anterior lobe of pronotum with four humps; forewings with two or four closed cells; about $5.4 \mathrm{~mm}$ or over $10 \mathrm{~mm}$ long (Figs 1-3)

8. Only first segment of beak spined; forewings with 4 closed cells; over $10 \mathrm{~mm}$ long

Buninotus

8.' All three segments of beak spined (Fig. 3); forewings with two closed cells (Fig. 1); about $5.4 \mathrm{~mm}$ long

Caprilesia gen. nov.

\section{Caprilesia gen. nov.}

Type species: Caprilesia almirantiana sp. nov.

Diagnosis. Head with posterior lobe subglobose (Figs 1-3); all three segments of beak with a pair of spines in the dorsal portion (Fig. 3). Pronotum dorsally with four rounded discrete elevations; humeral angles with a moderately long and sharp spine (Figs 1-3). Scutellum with long inclined spine; mesoscutum with spinelike elevation (Fig. 2). Forelegs with coxa, femur, and tibia spined; tibia recurved (Fig. 2). Forewings with two closed cells (Fig. 1). Body mostly stramineous, shiny, and glabrous.

Etymology. The generic name is in honor to the late Dr. Jenaro Maldonado Capriles (1919-1995) for his important contributions to the knowledge of the American reduviids.

\section{Caprilesia almirantiana sp. nov.}

Description. Female (Figs 1-5). Measurements (in millimeters). Total length 5.4 ; head length 0.7 ; antennal segments: I: 2.2; II: 0.9; III: 1.2; IV: 0.8; rostrum: total length 1.0; segments I: 0.5; II: 0.3: III: 0.2. Thorax: total length 2.0; pronotum: anterior lobe length: 0.5 ; width 0.6 ; posterior lobe length: 0.5 ; width 0.8 . Anterior legs: coxa 0.5 ; femur 1.8 ; tibia 1.7 ; tarsus 0.4 ; medium legs: femur 2.3; tibia 2.6; tarsus 0.3; posterior legs: femur 3.0; tibia 4.3; tarsus (absent). Abdomen: length 2.7; width 1.2.

General coloration yellowish brown to testaceous. Integument shiny, glabrous or covered with fine and sparse pilosity. Head with a well developed post-ocular constriction; posterior lobe subglobose; tylus rounded. Eyes median sized, not reaching the lower margin of head (Fig. 3). Antennal segments slen- 
der, with sparse pilosity; ventral portion of head with five pairs of setigerous spines (Fig. 3). Beak curved with a pair of dorsal spines in each segment; first with the pair of spines in the middle portion; the second shorter and somewhat inflated, mainly in the first third where the pair of spines are located; spines of the third segment shorter (Fig. 3). Neck well defined.

Pronotum dorsally with four rounded discrete elevations; humeral angles with a moderately long and sharp spine (Figs 13 ). Tegument a little darker in the pleural and sternal regions that possess bright pilosity a little more developed in the ventral portion of thorax. Forelegs: coxa with a long spine near base on anterior side (Figs 2-3); trochanter with four spines (Fig. 2), the median ones more developed; femur slightly curved, with ten spines along upper surface alternating shorter and longer ones; this last as long as thickness of segment (Fig. 2). Tibia little curved, thicker at apex that is also haired; dorsal side with six spines (Figs 1-2). Median and hind legs long, slender, sparsely haired and not spined (Figs 1-2). Forewings brownish, a little brighter in the basal portion; a transverse and curved yellowish band crossing over the discal cell at the widest area of the forewing (Fig. 1). Sternites yellowish brown, covered with a fine bright and sparse pilosity. Genital esclerites as in figures 4 and 5 .

Etymology. The name of the species is in honor to Almirante Centro de Estudos de Cacau, the Institution that has provided the financial support for the second author in his studies on reduviids living in Cocoa (Theobroma cacao Linnaeus) plantations in the State of Bahia, Brazil.

Discussion. Caprilesia gen. nov. is close to Paratagalis and Buninotus and can be separated by the characters given in the key.

Otherwise, Caprilesia almirantiana sp. nov. has an uncommon feature among Neotropical Saicinae represented by the coloration of forewings, whose yellowish band on a dark colored background is an aposematic model usually found in other subfamilies of Reduviidae, mainly Peiratinae.

Material examined. Holotype female, from BraziL, Bahia: Barro Preto [in the past, Lomanto Júnior] $\left(14^{\circ} 43^{\prime} \mathrm{S}, 39^{\circ} 22^{\prime} \mathrm{W}\right)$, XII.2004, O.M. Marques leg., Museu Nacional, Universidade Federal do Rio de Janeiro, Rio de Janeiro, Brazil.

\section{ACKNOWLEDGMENTS}

Dimitri Forero (Cornell University) for observations on the studied group and to Almirante Centro de Estudos de Cacau, by the financial support that made possible the collecting of the holotype.

\section{REFERENCES}

BuIN, R.L. 1990. Pseudosaica panamaensis, a new genus and species of assassin bug from Panama (Heteroptera: Reduviidae: Saicinae). Journal of the New York Entomological Society, New York, 98 (3): 347-351.

Blinn, R.L. 1994. Synopsis of the Saicinae (Heteroptera: Reduviidae) of America North of Mexico, with the description of a new species of Saica from the eastern United States. Journal of the New York Entomological Society, New York, 102 (1): 62-66.

Gil-Santana, H.R. \& O.M. Marques. 2005. Primeiro registro de Saica apicalis Osborn \& Drake para o Brasil e Pseudosaica florida (Barber), com notas taxonômicas e chave para os gêneros de Saicinae do Brasil (Hemiptera, Reduviidae). Revista Brasileira de Zoologia, Curitiba, 22 (2): 405-409.

Maldonado Capriles, J. 1981. A new Ghilianella and a new saicinae genus, Buninotus (Hemiptera: Reduviidae) from Panama. Journal of Agriculture of University of Puerto Rico, San Juan, 65 (4): 401-407.

Maldonado Capriles, J. 1990. Systematic Catalogue of the Reduviidae of the World (Insecta: Heteroptera). Caribbean Journal of Sciences, Mayagüez, special edition, 694p.

Melo, M.C. \& M.C. Coscarón. 2005. Saicireta correntina, a new genus and species of assassin bug from Argentina (Heteroptera, Reduviidae, Saicinae) with a key to the New World genera. Deutsche entomologische Zeitschrift, Berlin, 52 (2): 245-249.

Monte, O. 1943. Notas sôbre Saicinae (Hemiptera, Reduviidae). Revista Brasileira de Biologia, Rio de Janeiro, 3 (3): 361364.

Putshkov, V.G. \& P.V. Putshrov. 1985. A Catalogue of the AssassinBugs Genera of the World (Heteroptera, Reduviidae). Kiev, Published by the authors, 137p.

SchuH, R.T. \& J.A. SLATER. 1995. True bugs of the world (Hemiptera: Heteroptera): classification and natural history. New York, Cornell University Press, 336p.

Wygodzinsky, P. 1949. Elenco sistematico de los reduviiformes americanos. Instituto de Medicina Regional de la Universidad Nacional de Tucumán, Monografia 1: 1-102.

Received in 12.VIII.2005; accepted in 24.IV.2006. 